Falah: Jurnal Ekonomi Syariah

(p)ISSN: 2502-3918; (e)ISSN: 2502-7825

Vol 4, No 2 (Agustus 2019), pp.144-158

DOI: https://doi.org/10.22219/jes.v4i2.9872

\title{
Strategi Pengembangan Wakaf Berkelanjutan dalam Sektor Pertanian: Studi Kasus di Yayasan Pemeliharaan dan Perluasan Wakaf Pondok Modern (YPPWPM) Gontor Ponorogo
}

\author{
Eko Nur Cahyo \& Ahmad Muqorobin \\ Program Studi Hukum Ekonomi Syariah Fakultas Syariah \\ Universitas Darussalam (UNIDA) Gontor \\ Email: ekonuralmalowy@gmail.com
}

\begin{abstract}
The development of endowments land in the agricultural sector is very essential because it is one of the strengthening sectors of the Indonesian economy. This study aims to identify the development of sustainable endowments strategies through the agricultural sector at Yayasan Pemeliharaan dan Perluasan Wakaf Pondok Modern (YPPWPM), Pondok Modern Darussalam Gontor Ponorogo. To identify the endowments development strategies in the agricultural sector this research is qualitative. The result shows that Yayasan Pemeliharaan dan Perluasan Wakaf Pondok Modern (YPPWPM), Pondok Modern Darussalam Gontor Ponorogo carried out three factor systems for the sustainable development strategy. First, using the waqf land rental system. Second, the development by the management system. and thirdly, the profit sharing system with the concept of muzara'ah. On the other hand, the results of the SWOT analysis indicate that this model is worth continuing to develop sustainable endowments, so that the benefits of endowments can be fulfilled continuously.
\end{abstract}

Keywords: Endowments, Sustainable Endowments, Agriculture, Muzara'ah. 


\begin{abstract}
ABSTRAK
Pengembangan tanah abadi di sektor pertanian sangat penting karena merupakan salah satu sektor penguat perekonomian Indonesia. Penelitian ini bertujuan untuk mengidentifikasi pengembangan strategi dana abadi yang berkelanjutan melalui sektor pertanian di Yayasan Pemeliharaan dan Perluasan Wakaf Pondok Modern (YPPWPM), Pondok Modern Darussalam Gontor Ponorogo. Untuk mengidentifikasi strategi pengembangan wakaf di sektor pertanian, penelitian ini adalah kualitatif. Hasil penelitian menunjukkan bahwa Yayasan Pemeliharaan dan Perluasan Wakaf Pondok Modern (YPPWPM), Pondok Modern Darussalam Gontor Ponorogo melaksanakan tiga sistem faktor untuk strategi pembangunan berkelanjutan. Pertama, menggunakan sistem sewa tanah wakaf. Kedua, pengembangan oleh sistem manajemen. dan ketiga, sistem bagi hasil dengan konsep muzara'ah. Di sisi lain, hasil analisis SWOT menunjukkan bahwa model ini layak untuk terus mengembangkan dana abadi, sehingga manfaat dana abadi dapat dipenuhi secara terus menerus.
\end{abstract}

Kata Kunci: Wakaf, Wakaf Berkelanjutan, Pertanian, Muzara'ah.

\title{
1. Pendahuluan
}

Indonesia dikenal sebagai negara dengan jumlah penduduk muslim terbesar di dunia. Berdasarkan hasi survey, sekitar 207 juta jiwa (87\%) penduduk Indonesia beragama Islam (www.bps.go.id). Ditambah dengan prosentase 13\% muslim dunia menjadi bagian dari warga negara Indonesia. Berikutnya menyusul India (176 juta), Pakistan (167 juta), Bangladesh (133 juta), Nigeria (77 juta), Mesir (76 juta), Iran (73 juta), Turki (71 juta), Aljazair (34 juta) dan Maroko (31 juta) (www.pewforum.org.). Dominasi inilah yang dapat menjadi faktor pendukung dalam mengembangkan peran wakaf sebagai upaya positif untuk mengatasi problematika ekonomi dan kemiskinan yang nampaknya tak kunjung menemukan titik terang.

Wakaf merupakan salah satu institusi Islam yang sangat potensial. Dahulu, wakaf memiliki peran yang cukup signifikan tidak hanya pada aspek keagamaan namun juga aspek sosial. Meski sejarah wakaf di Indoensia sempat hanya berkisar pada persoalan ibadah, namun saat ini pemanfaatan wakaf sudah semakin beragam (Hasanah \& Hakim, 2017). Wakaf telah menjadi salah satu instrumen dalam ekonomi Islam yang memiliki spesifikasi khusus dan menjadi pembeda dibandingkan jenis filontropi yang lain (Pusparini, 2016).

Berdasarkan hasil survey Badan Wakaf Indonesia, saat ini jumlah tanah wakaf di Indonesia mencapai 361.954 lokasi dengan luas 49.283,92 Ha (Dir. 
Pemberdayaan Wakaf Kemenag RI, 2019). Jika besaran tersebut dikelola secara produktif dan maksimal, tentu dapat menjadi sarana dalam meningkatkan perekonomian. Di sisi lain, potensi wakaf uang merupakan solusi nyata dalam mengentaskan kemiskinan yang ada. Namun, terdapat beberapa kendala, antara lain: pengelolaan yang masih bersifat konvensional dan pemanfaatan yang konsumtif, sehingga belum mencapai standar produktif (Dirjen Bimas Islam, Dir. Pemberdayaan Wakaf, 2013).

Sehubungan dengan hal di atas, sebagian tanah wakaf dialihkan untuk sektor pertanian. Hal ini didasarkan pada Indonesia yang dikenal sebagai negara agraris dengan mayoritas penduduk bermata pencaharian sebagai petani. Akan tetapi, perkembangan zaman dan konversi lahan pertanian menjadi lahan non-pertanian menjadikan Indonesia tak lagi menjadi negara agraris.

Pondok Modern Darussalam Gontor (PMDG) sebagai salah satu lembaga pendidikan Islam berbentuk pesantren telah mengambil langkah untuk mewakafkan pondok menjadi milik umat pada tanggal 12 Oktober 1958. Adapun pengelolaan wakaf pondok berada di bawah tanggungjawab Yayasan Pemeliharaan dan Perluasan Wakaf Pondok Modern (YPPWPM). Dalam perjalanannya, keberadaan tanah wakaf yang luas dan tersebar di beberapa tempat menjadi salah satu tonggak perekonomian pondok, sehingga dapat menunjang stabilisasi dan pengembangan program pondok.

Pendayaguaan tanah wakaf Pondok Gontor terwujud dalam dua bentuk, yaitu: (1) pendayagunaan pokok, pesantren merupakan institusi penyelenggara pendidikan dari tingkat dasar sampai dengan tinggat perguruan tinggi. (2) pendayagunaan penunjang atau pengembangan, berkaitan dengan pengelolaan aset pondok yang menjadi 'donatur' utama dalam mengembangkan kesejahteraan pondok (https://Www.gontor.ac.id). Adapun YPPWPM memilih pengelolaan wakaf dalam sektor pertanian. Eksistensi, kemajuan, dan langkah Pondok Gontor dalam membangun beberapa sektor produktif saat ini merupakan bukti nyata keberhasilan YPPWPM dalam mengelola wakaf yang dimiliki. Wakaf produktif dapat juga dilakukan dengan memanfaatkan ribuan hektar wakaf yang tersebar di seluruh tanah air untuk kegiatan-kegiatan ekonomi bernilai tinggi. Dalam pengelolaan dengan potensi yang besar, maka pemberdayaan wakaf secara optimal dan berkelanjutan akan menjadi solusi alternatif bagi peningkatan kemampuan pada sektor pertanian. Apalagi jika wakaf tersebut dikelola oleh lembaga yang bertanggung jawab, misalnya lembaga pertanian YPPWPM.

Terdapat beberapa penelitian yang telah mengkaji tentang wakaf produktif, diantaranya adalah Huda (2009), menyimpulkan bahwa seorang nadzir wakaf pada pesantren masih memiliki kesadaran terhadap pentingnya kegiatan penggalangan sumber dana wakaf, demi keberlanjutan/keberlangsungan dan kemandirian program- program dan kegiatan di pesantren. Sementara Medias (2010), Penelitian ini menunjukkan bahwa: 1) wakaf tunai atau wakaf produktif di Indonesia dapat digunakan sebagai program untuk mengurangi kemiskinan. 2) 
untuk meningkatkan wakaf yang produktif dibutuhkan orang-orang profesional, berkomitmen, dan memahami bahwa wakaf tunai memiliki pengaruh besar terhadap perkembangan ekonomi. Sejalan dengan penelitian yang dilakukan oleh Suryani \& Isra (2016), memberikan hasil bahwa wakaf tunai dapat bersinergi dengan berbagai program pemerintah dalam mewujudkan kesejahteraan rakyat. Sesuai dengan fatwa MUI yang menyatakan bahwasanya wakaf uang merupakan upaya positif dalam mewujudkan kesejahteraan umat baik di dunia maupun di akhirat. Dahlan (2014), dalam penelitianya menyatakan bahwa persepsi nadzir dipengaruhi oleh akses terhadap media informasi dan pemahaman atas aturan mengenai wakaf, akan tetapi mayoritas nadzir setuju dengan adanya wakaf uang. Latar belakang pendidikan akan berpengaruh terhadap terbentuknya persepsi atau pemahaman nadzir, karena nadzir yang berpendidikan akan memiliki sikap terbuka terhadap informasi baru dan memandangnya secara obyektif. Sedangkan dari sisi wakif, Nizar (2014), melihat karakteristik responden yang merupakan wakif pada nadzir BWI berdasarkan demografi dan sosial ekonominya dan melihat hubungan antara faktor pendidikan, pendapatan, mazhab yang diikuti dan media informasi dengan persepsi wakif tentang wakaf uang. Hasil analisis data menunjukkan bahwa variabel pendidikan memiliki peluang yang lebih besar dan signifikan dalam menjelaskan persepsi wakif tentang wakaf uang.

Sementara menurut Imari \& Syamsuri (2017), menjelaskan bahwa perlu diadakan tahapan perencanaan, pengorganisasian, kepemimpinan lembaga hingga pengawasan untuk pemberdayaan harta wakaf agar hasilnya lebih maksimal.

Huda (2012), menyatakan bahwasanya kemandirian pesantren dapat ditopang dengan konsep sedekah/wakaf. Adapun pilar yang mendasari pengembangan pesantren wakaf adalah: (1) pengorbanan pendiri pesantren dengan mewakafkan harta miliknya untuk pesantren, (2) profesionalitas kelembagaan pesantren wakaf dalam badan hukum/yayasan, (3) pengelolaan harta wakaf secara produktif, dan (4) penyaluran hasil wakaf untuk internal pesantren maupun masyarakat. Hal ini tidak berbenturan dengan Undang-undang RI Nomor 41 tahun 2004 tentang wakaf. Sedangkan Rosadi, Effendi \& Busro (2018) menyatakan bahwa untuk menciptakan wakaf produktif maka yang perlu dibangun adalah aspek sosial yang meliputi suatu kepercayaan (trust), saling pengertian (mutual understanding) dan nilai-nilai bersama (shared value) untuk menghasilkan kontribusi besar terhadap keberlanjutan produktivitas wakaf.

Berdasarkan hal di atas, penelitian ini memiliki persamaan dengan beberapa penelitian yang tersebut dalam kaitannya dengan produktivitas pengelolaan wakaf dalam bidang pertanian, perdagangan, industri, dan berbagai usaha lainnya. Namun, penelitian ini mengambil fokus pada strategi pengembangan wakaf berkelanjutan pada sektor pertanian yang dilaksanakan oleh YPPWPM Gontor Ponorogo. Selanjutnya, dilakukan integrasi antara aspek kekuatan, kelemahan, peluang dan ancaman dalam pengembangan wakaf berkelanjutan pada sektor 
pertanian berdasarkan permasalahan yang ada, sehingga dapat diketahui kekuatan peluang dan perkembangannya di masa mendatang.

\section{Metode Penelitian}

Penelitian ini menggunakan metode kualitatif dengan pendekatan studi kasus. Metode kualitatif digunakan untuk menganalisa tujuan pertama dan kedua dari penelitian ini, yang pertama adalah untuk menganalisa strategi (YPPWPM) Pondok Gontor dalam mengembangkan wakaf berkelanjutan. Adapun tujuan kedua adalah menganalisa strategi (YPPWPM) Pondok Gontor dalam mengembangkan wakaf berkelanjutan pada sektor pertanian. Data dalam penelitian ini merupakan data kualitatif yang dikumpulkan dengan metode wawancara, observasi, Focus Group Discussion (FGD) dan dokumenter. Metode wawancara digunakan untuk menggali informasi dari pengurus yayasan, mandor petani dan petani. Sedangkan metode observasi dan dokumenter digunakan untuk memetakan kondisi internal dan eksternal (YPPWPM) Pondok Gontor. Sedangkan metode FGD dilakukan untuk mendapatkan informasi mendalam terkait strategi (YPPWPM) Pondok Gontor dalam mengembangkan wakaf berkelanjutan pada sektor pertanian.

Data-data yang telah terkumpul di analisa dengan beberapa alat analisa, yaitu: analisa deskriptif dan analisis SWOT. Analisa deskriptif digunakan untuk menganalisa peran strategi (YPPWPM) Pondok Gontor dalam mengembangkan wakaf berkelanjutan. Sedangkan analisa SWOT digunakan untuk meneliti strategi pengembangan wakaf berkelanjutan pada sektor pertanian. Selain itu, untuk mendapatkan hasil yang optimal dalam analisa SWOT digunakan pendekatan fenomenologis, yaitu dengan menganalisa fenomena yang terjadi pada objek penelitian dan sekitarnya.

\section{Wakaf: Definisi dan Bentuknya}

Kata wakaf berasal dari bahasa Arab yaitu waqf kemudian diserap ke dalam bahasa Indonesia menjadi wakaf, yang artinya habs berarti menahan, berhenti, diam di tempat atau berdiri (Fadlullah. 1925); (Munawir, 1994). Kata al-Waqf bentuk masdar dari ungkapan wakaftu asy-syai', yang berarti menahan sesuatu. Pengertian menahan dihubungkan dengan harta kekayaan, itulah yang dimaksud wakaf dalam bahasa ini. Artinya menahan harta untuk diwakafkan, tidak dipindahmilikkan (al-Syarbini al-Khatib, t.t). Sedangkan di Indonesia harta yang diwakafkan (al-mauquf bih) disebut sebagai pengertian institusi atau objek yang diwakafkan (Praja. 1995). Sementara jika wakaf ditinjau dari makna syara' para ulama fiqih berbeda pendapat dalam penafsiranya, akan tetapi hal yang disepakati bahwasanya wakaf adalah menahan zatnya dan menyedekahkan manfaatnya (Zahra. 1971). Sedangkan yang menjadikan perdebatan di antara para ulama fiqih dikarenakan cara penafsiran dalam memandang hakikat wakaf. 
Para ulama dalam menerangkan konsep wakaf didasarkan pada keumuman ayat-ayat Al-Qur'an yang menjelaskan tentang amal kebaikan. Beberapa ayat-ayat Al-Qur'an tersebut yaitu: (Q.S. Ali Imran[3]: 92), (Q.S. al-Baqarah[2]: 261). Salah satu yang menjelaskan tentang wakaf adalah hadis yang diriwayatkan oleh Al-Bukhari dan Muslim tentang wakaf Umar bin Al-Khatab ketika mendapatkan sebidang tanah di Khaibar, Umar mengeluarkan sedekah hasil tanah itu dengan syarat tanahnya tidak boleh dijual dan dibeli serta diwarisi atau dihadiahkan. Umar mengeluarkan sedekah hasilnya kepada fakir miskin, kaum kerabat, dan untuk memerdekakan hamba juga untuk orang yang berjihad di jalan Allah serta untuk bekal orang yang sedang dalam perjalanan dan menjadi hidangan untuk tamu. Orang yang mengurusinya boleh makan sebagian hasilnya dengan cara yang baik dan boleh memberi makan kepada temannya dengan sekadarnya.

Bentuk harta wakaf jika ditinjau dari segi jangka waktu atau keberlanjutannya, wakaf ini dibagi dua (2), yaitu : wakaf abadi atau kekal dan wakaf sementara yaitu terbatas dengan jangka waktu. Wakaf abadi ialah harta wakaf yang diwakafkan untuk masa yang tidak terbatas dan tetap berlanjut sepanjang zaman. Pemanfaatan wakaf seperti ini dapat digunakan dalam jangka waktu yang panjang, dan tidak habis dalam sekali pakai. Sesungguhnya model wakaf yang sebenarnya dalam Islam adalah wakaf abadi, wakaf yang manfaatnya berkelanjutan. Wakaf ini adalah yang biasa disebut sebagai shadaqah jariyah yang paling sempurna bentuknya. Pahala wakaf ini mengalir untuk pewakaf selama wakafnya terus berlangsung. Sedangkan wakaf sementara ialah wakaf yang sifatnya terbatas dengan waktu dan tidak abadi, dikarenakan dari bentuk barang yang diwakafkan atau keinginan wakif sendiri (Qahf, 2005). Dari bentuk penggunaan harta yang diwakafkan, dibagi menjadi dua yaitu: mubasyir/dzati ialah harta wakaf yang manfaatnya berupa pelayanan terhadap masyarakat dan dapat digunakan secara langsung seperti masjid, madrasah, dan rumah sakit. Sedangkan istitsmary adalah harta wakaf yang diperuntukkan untuk penanaman modal usaha atau pelayanan yang dibolehkan syariat Islam dalam bentuk apa saja yang kemudian hasilnya diwakafkan sesuai keinginan waqif (Qahf, 2005).

\subsection{Sejarah Pengembangan Wakaf di Pondok Modern Gontor}

Dalam Badan Wakaf Pondok Modern Gontor, ikrar wakaf sebenarnya telah terjadi sejak tahun 1951, bertepatan dengan ulang tahun seperempat abad pondok pesantren ini. Pada tahun itu, telah diucapkan semacam ikrar bahwa pondok Modern Gontor milik seluruh umat Islam dan bahwa maju mundurnya pondok tergantung kepada kesadaran umat Islam sendiri sebagai pemiliknya. Namun karena penyerahan ini belum memiliki kekuatan legal formal, banyak pihak yang meragukan keabsahan ikrar tersebut. Maka dalam rangka memenuhi legalitas tersebut, pada tanggal 12 Oktober 1958, wâqif atas nama pendiri Pondok Modern Gontor yang biasa dipanggil "Trimurti", menandatangani piagam penyerahan 
wakaf Pondok Modern Gontor Ponorogo kepada 15 wakil dari Ikatan Keluarga Pondok Modern (IKPM), yang merupakan alumni Pondok Modern Gontor.

Harta wakaf yang diserahkan pada saat itu terdiri dari tanah basah atau sawah (1,74 Ha), tanah kering (16,85 ha) dan 12 gedung serta perlengkapannya. Harta wakaf tersebut sebagiannya berasal dari peninggalan orang tua Trimurti, sedangkan sebagian lainnya diperoleh dari bantuan masyarakat yang bersimpati kepada Pondok. Apalagi sejak tahun 1931 PM Gontor telah membentuk Khizânah, sebuah badan khusus yang bertugas melakukan penggalangan dana yang hasilnya kemudian dibelikan sawah.

Selain untuk tujuan beribadah, ada beberapa alasan yang menggerakkan Trimurti secara sukarela mewakafkan harta bendanya. Para pendiri pondok tentu sangat prihatin dengan kenyataan bahwa pada masa lalu, jarang ada pesantren yang bertahan lama sepeninggal pendirinya. Ini karena pesantren itu pada umumnya milik kiai dan apabila sang kiai wafat maka akan digantikan oleh putranya dan kemudian keturunannya. Di sisi lain, pesantren sangat tergantung pada kharisma sang kiai. Akibatnya apabila tidak ada keturunan kiai yang mumpuni dan karismatik, maka pesantren akan kehilangan dukungan masyarakat, dan pada gilirannya akan sulit bertahan sepeninggal sang pendiri. Inilah realitas yang menimpa kebanyakan pesantren besar masa lalu (Tim Penulisan Riwayat Hidup dan Perjuangan K.H. Imam Zarkasyi, 1996).

Alasan lainnya adalah tidak ada kepastian hukum mengenai kepemilikan tanah atau harta benda pesantren. Sering tidak ada batas pemisah yang jelas antara hak milik pesantren dan hak milik keluarga kiai, yang pada tataran selanjutnya menimbulkan konflik dan keributan. Konflik internal ini biasanya timbul karena tidak adanya sebuah sistem yang dapat mengelola dengan baik antara kepentingan keluarga dan pondok. Trimurti tampaknya melihat bahwa institusi wakaf dapat menjadi alat yang tepat guna mengatasi konflik yang mungkin timbul di kemudian hari. Apalagi institusi wakaf dalam sejarah Islam, sangat besar pengaruh dan manfaatnya seperti universitas Al-Azhar Mesir ataupun universitas Islam di era keemasan Islam.

Visi dan misi badan wakaf Gontor ada lima butir penting yang merupakan amanat Trimurti kepada badan wakaf selaku nâdzir. Pertama, pondok modern ini harus tetap menjadi kegiatan sosial keagamaan (amal jâriyah), yang tunduk kepada aturan dalam agama Islam. Kedua, Pondok modern harus tetap menjadi sumber ilmu-ilmu agama, ilmu umum, bahasa Arab, namun berjiwa pesantren. Ketiga, Pondok modern ini adalah lembaga pengabdian masyarakat dalam artian membentuk karakter umat guna kesejahteraan lahir dan batin. Keempat, Pondok modern harus dipelihara dan dikembangkan agar kelak menjadi sebuah universitas Islam yang bermutu dan berarti. Kelima, untuk menjamin agar amanat tersebut memiliki kekuatan hukum formal, maka badan wakaf harus segera mempunyai akta notaris (Pondok Modern Gontor, t.t). 
Badan Wakaf Pondok Modern Gontor tidak langsung mengurus, memelihara dan memperluas harta wakaf, tapi mendelegasikan wewenang tersebut kepada pimpinan pondok sebagai mandatarisnya. Dalam struktur organisasi Balai Pendidikan Gontor, Badan Wakaf menempati kedudukan tertinggi sebagai lembaga legislatif yang memiliki tugas dan wewenang yang luas. Lembaga ini berfungsi memutuskan dan menetapkan kebijakan yang terkait dengan semua proses pendidikan di Pondok, menetapkan visi dan misi, aturan-aturan dan statuta lembaga di bawahnya, serta memilih dan menetapkan pimpinan pondok serta pimpinan lembaga di bawahnya (Bamualim \& Abubakar (ed.), 2005).

Selanjutnya yang bertugas dan bertanggung jawab atas pembiayaan dan pemeliharaan Balai Pendidikan Pondok Modern Gontor dengan segala milik dan kekayaannya adalah Yayasan Pemeliharaan dan Perluasan Wakaf Pondok Modern (YPPWPM). Yayasan ini didirikan pada tanggal 18 Maret 1959, setahun setelah pelaksanaan ikrar wakaf, sesuai pasal 7 ART Badan Wakaf. Dalam mengelola dan memelihara tanah wakaf, yayasan dibantu oleh para pengawas yang juga disebut nâdzir. Para nâdzir tersebut berasal dari daerah di sekitar tempat sawah tersebut berada. Mereka bertanggung jawab kepada yayasan kemudian keduanya dapat melakukan evaluasi bersama. Tugas lainnya yaitu mengusahakan kepastian hukum tanah-tanah wakaf milik pesantren dengan cara menyertifikasinya sesuai aturan yang ada (Bamualim \& Abubakar (ed.), 2005).

Berikut rekapitulasi perluasan tanah wakaf PM Gontor yang dilakukan oleh YPPWPM, selam tiga tahun terakhir dari tahun 2016-2018.

Tabel 1.1

Perluasan Tanah Gontor 2016-2018

\begin{tabular}{ccc}
\hline No & Tahun & Luas $\mathbf{M}^{\mathbf{2}}$ \\
\hline 1. & 2016 & 11.081 .968 \\
\hline 2. & 2017 & 12.620 .269 \\
\hline 3. & 2018 & 12.643 .712 \\
\hline & Sumber : Data Diolah, 2018
\end{tabular}

Selama tiga tahun terakhir perluasan tanah wakaf Gontor selalu bertambah. Tanah wakaf tersebut tersebar di 24 daerah di seluruh Indonesia. Dengan segala kemampuan yang ada, program perluasan tanah YPPWPM bisa berjalan dengan baik. Perluasan dan pengembangan tanah diperoleh melalui penerimaan tanah bersifat wakaf dan pembelian tanah baru (Warta Dunia Pondok Modern Darussalam Gontor, $1439 \mathrm{H}$ ). Adapun harta wakaf yang berbentuk sarana dan prasarana lainnya seperti bangunan masjid, asrama, madrasah, kampus dan sebagainya tersebar di seluruh pondok-pondok cabang Gontor, yaitu Gontor putra 14 cabang dan Gontor putri mencapai 7 cabang.

Selain mengintensifkan pengurusan tanah wakaf, yayasan juga menggali dana-dana dari luar hasil tanah wakaf, baik yang diperoleh dari Zakat Infaq dan 
Sadaqah (ZIS) maupun dana tidak langsung lainnya seperti investasi. Untuk memperlancar strateginya ini, yayasan memanfaatkan jaringan alumni di dalam dan di luar negeri, khususnya mereka yang berprofesi sebagai pengusaha. Untuk melaksanakan tugasnya, yayasan membentuk bagian-bagian, antara lain bagian pemeliharaan dan pertanian, yang bertugas memelihara tanah dan lahan pertanian serta mengelola hasilnya. Bagian kedua adalah berkenaan dengan perluasan dan peralatan yang bertugas menangani usaha-usaha perluasan wakaf dan mengurus status hukum dan administrasi pertanahannya. Bagian ketiga adalah berkenaan dengan pergedungan dan peralatan dan bertanggung jawab memelihara dan menambah sarana pergedungan dan peralatan untuk kepentingan pendidikan dan pengajaran.

\section{Strategi Pengembangan Wakaf Berkelanjutan pada Sektor Pertanian di YPPWPM Gontor}

Berawal dari penyerahan Wakaf Pondok Modern Darussalam Gontor dari para Pendirinya kepada Badan Wakaf, berarti para wakif telah melepaskan hak milik pribadinya secara turun temurun demi kepentingan Islam, umat Islam, dan pendidikan Islam. Dengan demikian Pondok Modern Darussalam Gontor secara resmi telah berpindah status dari milik pribadi menjadi milik institusi yang dalam hal ini diwakili oleh Badan Wakaf. Sedangkan untuk memelihara dan mengembangkan kekayaan yang diwakafkan tersebut dilimpahkan sepenuhnya oleh YPPWPM.

Yayasan ini berkewajiban melaksanakan kebijaksanaan-kebijaksanaan Pimpinan Pondok Modern Darussalam Gontor, yang menjadi tanggung jawab oleh ketua yayasan. Struktur kepengurusan terdiri dari ketua, wakil ketua, sekretaris, bendahara, bagian inventaris, bagian pertanian, dan pertanahan. Dalam rangka penggalian dana untuk berbagai kepentingan pondok, anggota pengurus yayasan mendirikan koperasi yang disebut Koperasi Pondok Pesantren (Kopontren). Aset yayasan meliputi seluruh aset dan kekayaan yang dimiliki pondok dalam berbagai bentuk (Anggaran dasar jajasan-jajasan pemeliharaan dan perluasan wakaf pondok modern No. 24, 1959).

Dalam pengelolaan tanah wakaf tersebut, terdapat aset yang produktif dan non produktif. Aset tanah non produktif dikelola dengan membangun sebuah bangunan sebagai interaksi pendidikan antara guru dan peserta didiknya sesuai dengan yang telah diorientasikan pondok Modern Darussalam Gontor. Sedangkan untuk aset tanah yang produktif dalam pengelolaannya digunakan salah satunya untuk sektor pertanian. Berdasarkan hasil wawancara dengan ketua YPPWPM Gontor, Ahmad Shobari, terdapat tiga sistem kerjasama yang dilakukan oleh YPPWPM Gontor dalam usaha pengembangan tanah wakaf pada sektor pertanian (Wawancara, H. Imam Shobari, 2019).

Pertama, sistem sewa lahan. Kedua, ditanam sendiri oleh pengelola YPPWPM Gontor, namun hasilnya dirasakan kurang begitu maksimal, dan 
Ketiga, sistem bagi hasil dengan penggarap sawah. Adapun model pengembangan wakaf berkelanjutan pada sektor pertanian adalah sebagai berikut:

Gambar 1.1

Model Pengembangan Wakaf Berkelanjutan di Yayasan Pemeliharaan dan Perluasan Wakaf Pondok Modern (YPPWPM) Gontor Ponorogo

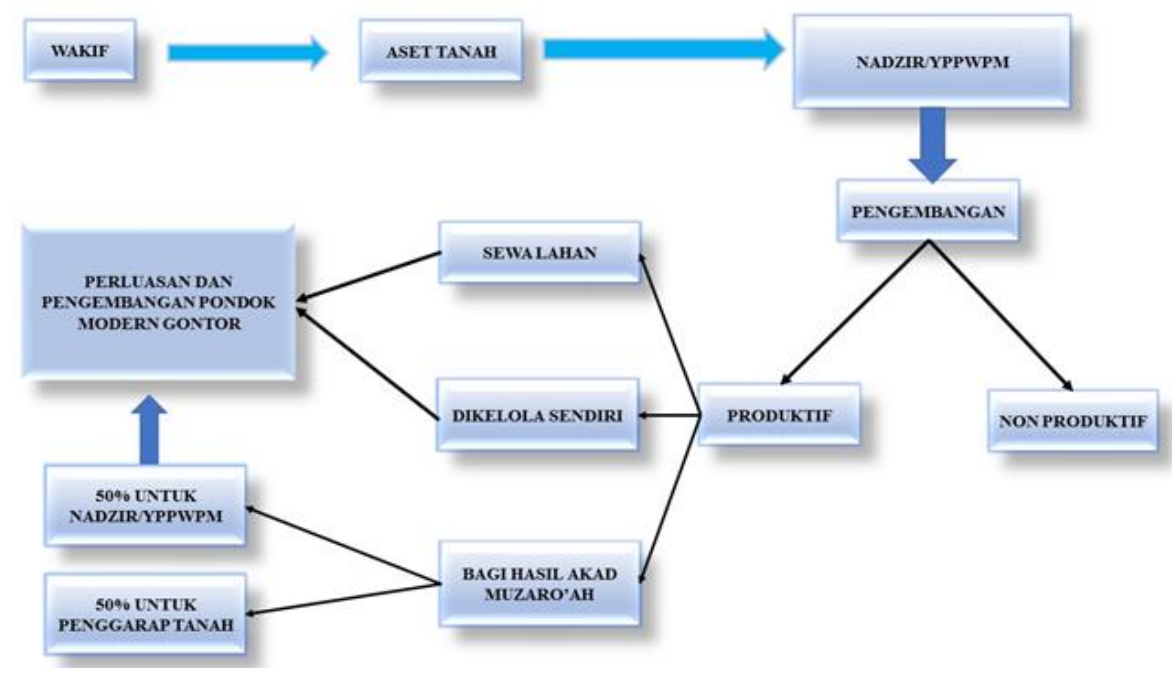

Sumber : Data diolah, 2018

4.1. Pengembangan tanah wakaf dengan sistem sewa lahan

Jenis tanah yang dikembangkan dalam sektor pertanian adalah jenis tanah kosong yang basah. Tanah tersebut dapat dijadikan sebagai lahan pertanian. Strategi yayasan dalam mengembangkan tanah wakaf tersebut salah satunya dengan sistem sewa lahan. Yayasan bekerjasama dengan para petani atau penggarap sawah yang ingin mengelola tanah tersebut dengan kontrak sewa.

Jenis tanaman yang di tanam mayoritas padi, karena tergantung jenis tanah yang disewa. Tanah yang berbentuk lerengan ditanami dengan pohon jeruk. Sedangkan tanah di daerah Ponorogo, Nganjuk dan Kediri dikelola dengan ditanami padi, hanya sebagian kecil tanah di Ngawi yang ditanami tebu.

Pihak yayasan menawarkan harga sewa dengan melihat harga pasar di sekitar tanah tersebut. Dari hasil wawancara, bahwa harga sewa tanah yang diberikan YPPWPM Gontor adalah harga paling murah di bandingan harga sewa tanah yang lainya. Akan tetapi dengan harga tersebut tidak merusak pasar, karena salah satu tujuannya ingin membantu masyarakat sekitar atau penyewa yang kurang mampu. harga sewa tersebut dapat di rata-rata sekitar Rp 2.000.000,- per petak sawah dengan luas $1.400 \mathrm{~m}^{2}$.

Setelah terjadi kesepakatan sewa-menyewa antara kedua belah pihak, yayasan menerima hasil sewa di awal kontrak. Akad sewa minimal selama 1 tahun, dan apabila ingin melanjutkan sewa bisa memperpanjang setelah satu 
tahun. Selama ini kontrak sewa dilakukan sebatas lisan, belum ada kontrak secara tertulis. Selanjutnya, pihak yayasan akan menyediakan kontrak tertulis sehingga transparansi dapat diketahui oleh kedua belah pihak.

Strategi pengembangan tanah wakaf dengan sistem sewa lahan dapat menjadikan lahan wakaf menjadi produktif. Hasil dari sewa tersebut dimanfaatkan oleh yayasan untuk kesejahteraan umat dan juga untuk pengembangan dan perluasan pondok modern Gontor.

\subsection{Pengembangan tanah wakaf dengan pengelolaan sendiri oleh YPPWPM Gontor}

Bentuk pengembangan tanah wakaf yang kedua dikelola secara mandiri. Maksudnya, pihak yayasan sebagai nadzir mengelola tanah wakaf tersebut. Lahan wakaf ditanami pohon durian yang berada di daerah Trenggalek dan kebun sawit di daerah Jambi. Sedangkan tanah wakaf yang di sekitar pondok ditanami padi. Di setiap daerah tersebut ada yang bertanggung jawab untuk mengontrol dan mengawasi proses pengelolaan tanah dan pohon yang ditanam. Kemudian setiap bulanya wajib melaporkan kepada yayasan pusat tentang hasil keuangan dan kebutuhan operasional yang diperlukan.

Yayasan mempekerjakan tenaga profesional untuk mengelola lahan tersebut, dari mulai penanaman, perawatan sampai waktu memanen. Semua kebutuhan operasional difasilitasi oleh pihak yayasan. Selanjutnya, dari hasil tanaman tersebut kemudian dikelola oleh yayasan untuk pengembangan dan perluasan Pondok Modern Darussalam Gontor (Wawancara, H. Imam Shobari, 2019).

\subsection{Pengembangan tanah wakaf dengan sistem bagi hasil}

Untuk pengembangan tanah wakaf dengan sistem bagi hasil, mayoritas tanah yang berbentuk sawah. Tanah tersebut berada di daerah Ngawi. Pihak pengelola atau yayasan bekerjasama dengan masyarakat sekitar untuk mengelola lahan tersebut. Hal ini, merupakan salah satu yang merujuk dari orientasi Gontor yaitu kemasyarakatan.

Pengembangan tanah wakaf tersebut diperuntukkan pada sektor pertanian. Selanjutnya harta wakaf tersebut oleh nadzir di distribusikan kepada masyarakat dalam bentuk lahan pertanian yang harus di kelola masyarakat dengan maksimal. Pendistribusian tersebut dilakukan dengan sistem bagi hasil antara kedua belah pihak menggunakan akad muzara'ah. Pihak yayasan sebagai pemilik lahan yang menyediakan segala keperluan untuk penggarapan sawah. Yayasan menyiapkan benih, alat bajak atau traktor, pengairan dan obat-obatan. Sedangkan masyarakat sebagai pengelola lahan tersebut.

Sistem bagi hasil dilakukan atas kesepakatan bersama, yaitu 50\%-50\% dari hasil bersih setelah panen. Bagian 50\% untuk penggarap sawah dan 50\% untuk disumbangkan kepada Pondok Modern Darussalam Gontor, untuk perluasan dalam pengembangan pembelajaran Pondok tersebut. Sumbangan 
tersebut selanjutnya akan dikelola oleh YPPWPM untuk keperluan maslahat umat seperti pendidikan, kesehatan dan ekonomi di Pondok Gontor.

Setiap minggunya diadakan pengajian untuk para penggarap sawah, dan juga pengarahan oleh pimpinan pondok. Hal ini, dijadikan sebagai media pengontrolan dan evaluasi dan koordinasi dengan para petani. Selain itu, yayasan juga bekerja sama juga dengan para penggarap sawah dalam memilih benih padi yang terbaik, dan berkualitas. Dengan harapan padi yang dihasilkan berkualitas dan dapat dipasarkan dengan harga tinggi. Hal itu untuk meningkatkan kesejahteraan pondok dan juga peningkatan hasil sektor pertanian (Wawancara, Muhammad Henry, 2019).

Untuk dapat melaksanakan sebuah ide atau pemikiran tentunya harus dapat menganalisis beberapa faktor internal (strength dan weakness) dan faktor eksternal (opportunity dan threat) untuk melihat apakah masyarakat dapat menerima gagasan ini secara keseluruhan.

1. Faktor Internal (strength dan weakness)

a. Kekuatan (strength)

1) Dengan memanfaatkan tanah wakaf yang ada untuk dikelola dan dikembangkan menjadi lahan pertanian yang dapat menyerap banyak tenaga kerja dari Desa di sekitar lahan tersebut dan diharapkan dapat menurunkan tingkat urbanisasi.

2) Jika terjadi penambahan wakaf tanah dalam setiap tahunya maka lahan pertanian pun semakin luas, dengan program pengelolaan wakaf berkelanjutan di sektor pertanian akan membantu pencapaian target pemerintah Indonesia dalam swasembada pangan setiap tahunnya.

3) Wakaf sustainable yang dirancang ini dapat mendorong proses pembangunan. Sebagai contoh yang telah dilakukan oleh YPPWPM Gontor. Keuntungan dari wakaf tanah tersebut dijadikan lahan pertanian kemudian diwakafkan kembali untuk keperluan umat dalam mendukung proses pembelajaran di Pondok Modern Gontor.

4) Dikarenakan sistem yang dirancang adalah wakaf sustainabel, maka pembangunan dari hasil wakaf tersebut akan semakin meluas, merata dan cepat.

5) Bentuk wakaf yang diberikan kepada masyarakat sesuai kebutuhannya misalnya berupa peralatan pertanian. Hal tersebut sangat membantu sebagaimana yang telah dilakukan oleh YPPWPM terhadap masyarakat sekitar.

b. Kelemahan (Weakness)

1) Dikarenakan program wakaf sustainabel ini masih tergolong baru, kesulitan utama yang dihadapi dalam pelaksanaannya adalah masih terbatasnya tenaga ahli yang akan menjalankannya.

2) Belum adanya aturan khusus yang dibuat untuk mengawasi proses dan laporan program wakaf sustanable ini.

2. Faktor Ekstrnal (opportunity dan threat)

a. Peluang (opportunity) 
1) Indonesia adalah negara dengan penduduk mayoritas muslim. Maka untuk mengenalkan program wakaf sustainabel kepada masyarakat cukup mudah.

2) Mayoritas penduduk Indonesia yang muslim memiliki potensi yang tinggi dalam penghimpunan tanah wakaf.

3) Tingkat kepedulian sosial penduduk Indonesia masih sangat tinggi, terutama masyarakat pedesaan di sekitar Pondok Gontor.

4) Status Pondok Gontor sudah diwakafkan oleh pendirinya, dan mayoritas berbentuk tanah wakaf yang kosong. Hal ini memiliki peluang yang sangat tinggi untuk dikembangkan dalam sektor pertanian dan kesejahteraan masyarakat sekitar.

b. Ancaman (threat)

1) Tidak semua masyarakat didaerah akan secara cepat menerima keberadaan pihak luar dengan segala ide dan informasinya.

2) Masyarakat muslim yang tersebar di masing-masing daerah memiliki pemahaman yang berbeda-beda terkait wakaf sustainabel.

3) Pengelolaan wakaf sustainable yang dilakukan oleh orang yang tidak bertanggung jawab akan memberikan dampak buruk terhadap program ini.

\section{Kesimpulan}

Bentuk harta wakaf jika ditinjau dari segi jangka waktu atau keberlanjutannya, wakaf ini dibagi dua (2), yaitu : wakaf abadi atau kekal dan wakaf sementara yaitu terbatas dengan jangka waktu. Wakaf abadi ialah harta wakaf yang diwakafkan untuk masa yang tidak terbatas dan tetap berlanjut sepanjang zaman. Sedangkan wakaf sementara ialah wakaf yang sifatnya terbatas dengan waktu dan tidak abadi, dikarenakan dari bentuk barang yang diwakafkan atau keinginan wakif sendiri. Dari segi pengelolaan wakaf, dikelola secara produktif dan non produktif. Seperti halnya yang telah diterapkan di YPPWPM Gontor, bahwa pengelolaan tanah wakaf secara produktif dan non produktif dengan jenis wakaf yang abadi. Aset tanah non produktif dikelola dengan membangun sebuah bangunan sebagai interaksi pendidikan antara guru dan peserta didiknya sesuai dengan yang telah diorientasikan pondok Modern Darussalam Gontor. Sedangkan untuk aset tanah yang produktif dalam pengelolaannya digunakan salah satunya untuk sektor pertanian. Terdapat tiga sistem kerjasama yang dilakukan oleh YPPWPM Gontor yaitu, Pertama, sistem sewa lahan. Kedua, ditanam sendiri oleh pengelola YPPWPM Gontor dan Ketiga, sistem bagi hasil dengan penggarap sawah. Hasil analisa SWOT menjelaskan bahwa pengembangan lahan wakaf pada sektor pertanian yang di terapkan YPPWPM Gontor sangat strategis. Sehingga melalui hasil dari sektor tersebut dapat dikembangkan untuk pembangunan sektor lainnya seperti pendidikan, kesehatan, ekonomi dan juga perluasan tanah wakaf. 


\section{Daftar Pustaka}

Al-Faraghani, Fakhr al-Din Hasan bin Mansur al-Hanafi, 1307 H. al-Fatawa alHindiyyah. Cet 2, J. 2. Qaherah: al-Amriyyah Bullaq.

Al-Hamawy, Yaqut ibn Abdullah. 1938 H. Mu'jam al-Udaba'. J. 7, Kairo: Dar alMa'mun.

Al-Humam, Ibnu. Kamal al-Din Muhammad bin Abd Allah al-Hanafi. 1970. Sharh Fath al-Qadir. J. 6. Qaherah: Mustafa al-Babi al-Halabi.

Ali, Muhammad Daud. 1988. Sistem Ekonomi Islam Zakat dan Wakaf. Jakarta: UI-Press.

Al-Jaziri, Abd al-Rahman. (t.t). Al-Fiqh 'ala Mazahib al-'Arba'ah. Bairut: Dar alQalam.

Al-Siba'i, Mushtafa. 1420 H. Min Rawa’i Hadaratina. Dar al-Warraq.

Al Syarbini, Mughni al Muhtaj. J. II. Mesir: Mustafa al-Bab al-Halaby.

Al-Syarbini, M. al-Khatib. (t.t). al-Iqna fi al-Hall al-Alfadz Abi Syuza'. Indonesia: Dar al-Ihya al-Kutub.

Ash-Shiddieqi, Hasbi. 1984. Pengantar Fiqh Muamalah. Jakarta: Bulan Bintang.

Badan Pusat Statistik (BPS), Sensus Penduduk Tahun 2010, (www.sp2010.bps.go.id).

Chaider S. Bamualim \& Irfan Abubakar (ed.), 2005. Revitalisasi Filantropi Islam: Studi Kasus Lembaga Zakat dan Wakaf di Indonesia. Jakarta: PBB UIN Syarif Hidayatullah dan Ford Foundation.

Pasaribu, Chairuman. dan Lubis, Suhrawardi K. 1996. Hukum Perjanjian Dalam Islam. Cet. II. Jakarta: Sinar Grafika.

Dahlan, Rahmat. 2014. Faktor-Faktor Yang Mempengaruhi Persepsi Nazhir Terhadap Wakaf Uang. Al-Iqtishad: Jurnal Ilmu Ekonomi Syariah, 6(2).

Direktorat Pemberdayaan Wakaf Kementerian Agama RI, 14 Maret 2016, Data Tanah Wakaf Seluruh Indonesia

Dokumentasi. 1959. Anggaran Dasar Jajasan-Jajasan Pemeliharaan dan Perluasan Wakaf Pondok Modern No. 24. Ponorogo: Pengadilan Negeri.

Fadlullah, Muhammad. 1925. Kamus Arab-Melayu, J. I. Jakarta: Balai Pustaka.

Fikry, Sayyid Ali. Al-Muamalat al Maddiyyah wa al Adabiyyah. J. II. Beirut: Dar al Kuutub al Arabiyyah.

Hasan, M. Ali. 2003. Berbagai Macam Transaksi dalam Islam (Fiqh Muamalat). Ed. 1. Cet.I. Jakarta: PT Raja Grafindo Persada.

Hasanah, Idaul \& Hakim, Rahmad. 2017. PELESTARIAN HUTAN KOTA MELALUI OPTIMALISASI WAKAF TUNAI. "Proseding Seminar Nasional Biologi". Malang: Universitas Muhammadiyah Malang Press. (http://research-report.umm.ac.id/index.php/researchreport/article/view/1010)

Huda, Miftahul. 2012. Wakaf dan Kemandirian Pesantren dari Tebuireng Hingga Gontor. ISLAMICA: Jurnal Studi Keislaman. 7(1).

. "Fundraising Wakaf dan Kemandirian Pesantren (Strategi Nadzir Wakaf Pesantren dalam Menggalang Sumber Daya Wakaf)", Makalah dipresentasikan pada The $9^{\text {th }}$ Annual Conference on Islamic Studies (ACIS), Surakarta 2-5 November 2009.

Imari, Iqbal dan Syamsuri. 2017. Pemberdayaan Waqf Produktif sebagai Media Pembangunan Ekonomi Pesantren: Satu Analisa Mekanisme Pelaksanaanya di Pesantren Wali Songo Ngabar. Islamic Economic Journal, 3(1).

Falah: Jurnal Ekonomi Syariah 
Kementrian Agama RI Direktorat Jendral Bimbingan Masyarakat Islam Direktorat Pemberdayaan Wakaf. 2013. Pedoman Pengembangan dan Pengelolaan Wakaf. Jakarta.

Medias, Fahmi. 2010. Wakaf Produktif Dalam Perspektif Ekonomi Islam. La_Riba Jurnal Ekonomi Islam, 4(1).

Munawir, A.W. 1994. Kamus Al-Munawir Arab-Indonesia. Yogyakarta: Pustaka Progresif.

Nizar, Ahmad. 2014. Faktor-Faktor Yang Mempengaruhi Persepsi Wakif Tentang Wakaf Uang. Esensi: Jurnal Bisnis dan Manajemen. 4(1).

Praja, Juhaya S. 1995. Perwakafan di Indonesia: Sejarah, Pemikiran, Hukum dan Perkembangannya. Bandung: Yayasan Piara.

Pew Research Center's Forum on Religion and Public Life. 2012. Data Pew Forum's forthcoming report on the world's Muslim population. (www.pewforum.org.)

Pondok Modern Gontor, (t.t). Sedjarah Balai Pendidikan Pondok Modern Gontor Ponorogo. Ponorogo: (t.p).

Pondok Pesantren Darussalam Gontor. 1439 H. Warta Dunia Pondok Modern Darussalam Gontor. Vol. 71. Ponorogo.

Pusparini, Martini Dwi. 2016. Konsep Wakaf Tunai Dalam Ekonomi Islam: Studi Pemikiran Abdul Mannan. Falah: Jurnal Ekonomi Syariah, 1(1); 14-28

Qahf, Mundzir. 2005. Manajemen Wakaf Produktif. Cet. 1. Jakarta: Khalifa.

Rosadi, Aden dll, 2018. The Development of Waqf Management Throught Waqf Act in Indonesia (Note on Republic of Indonesia Act Number 41 of 2004 on Waqf), Madania: Jurnal Kajian Islam, 22(1).

Sabiq, Sayyid. 1997. Fiqih Sunnah. Bandung: Al-Ma'arif.

Shalih al-Shalih, Muhammad ibn Ahmad ibn. 2001. al-Waqf fi al-Syari'ah wa Atsruhu fi Tanmiyah al-Mujtama. Saudi Arabia: Fihrisah Maktabah al-Malik Fahd al-Wathaniyah.

Suryani \& Yunal Isra. 2016. Wakaf Produktif (Cash Waqf) Dalam Perspektif Hukum Islam dan Maqashid Al-Shari'ah. Walisongo: Jurnal Penelitian Sosial Agama, 24(1).

Tim Penulisan Riwayat Hidup dan Perjuangan K.H. Imam Zarkasyi. 1996. K.H.Imam Zarkasyi: Dari Gontor Merintis Pesantren Modern. Ponorogo: Gontor Press.

Zahra, Abu. 1971. Muhadharat fi al-Waqf. Beirut: Dar al-Fikr al-'Arabi.

Wawancara. Al-Ustadz H. Imam Shobari, Pada Tanggal 21/06/2019. Kantor YPPWPM.

Wawancara. Al-Ustadz Muhammad Henry, S.Pd.I, dan Al-Ustadz Arfian Pada Tanggal 24/06/2019. Kantor YPPWPM.

https://www.gontor.ac.id/lembaga/profil-pondok-modern-darussalam, diakses pada tanggal : 5 Juni 2019, 11:21

https://www.republika.co.id/berita/dunia-islam/wakaf/17/12/08/p0mubc396wakaf-dapat-capai-tujuan-pembangunan-berkelanjutan. Diakses pada tanggal 10 Februari 2019, 10:25. 